http://doi.org/10.46754/gtc.2021.11.043

\title{
INFLUENCING FACTORS OF 7PS ON CONSUMER PURCHASE INTENTION OF HALAL TOURISM IN KANO-NIGERIA
}

\author{
Sulaiman Yahya ${ }^{1}$ \& Shaizatulaqma Kamalul Ariffin ${ }^{2}$ \\ ${ }^{1,2}$ Graduate School of Business, Universiti Sains Malaysia \\ (bnyahya1@yahoo.com)
}

\begin{abstract}
Halal Tourism is a social, cultural and economic phenomenon which entails the movement of people to countries or places outside their usual environment for personal or business/professional purposes in accordance with Islamic injunctions. Nigeria has a Muslim population of more than 100 million which makes it an ideal halal marketplace worth trillions of US dollars. As the halal movement gains traction, the global industry has set its sights on Nigeria's growing demand for shariah-compliant goods and services. The purpose of this paper is to examine the marketing mix strategy for halal tourism consisting of products, prices, promotions, locations, personal preferences, processes and physical evidence of the intent to partake in halal tourism by consumers in Kano-Nigeria. This research paper observes that Nigeria as a country has the potential to make tourism a main source of income seeing as it has a diverse set of tourist attractions, a large domestic tourism market and a unique cultural heritage capable of enticing foreign tourists. This research paper recommends among other things that the entrenchment of a sound halal tourism development master plan capable of rejuvenating the economy of the country and ensuring sustainable halal tourism development even in the face of the current global economic melt-down due to the COVID-19 pandemic. The paper employs the Desk Study approach as its method for gathering the data to be used in this study. The findings of this research paper will benefit those in tourism-related industries and policymakers. The specific identification of certain elements namely: products, prices, promotions, locations, personal preferences, processes and physical evidence of a consumer's intention to partake in halal tourism in Kano-Nigeria would help halal tourism service providers to offer attractive packages that meet tourist expectations. This paper has its limits as it is a conceptual approach, and empirical studies are both recommended and needed in the future.
\end{abstract}

KEYWORDS: Halal tourism, purchase intention, service marketing mix strategy, Kano.

\section{PURPOSE AND BACKGROUND}

The tourism industry is potentially a key economic driver of a nation, especially for developing countries like Nigeria and Malaysia, which are looking to diversify their revenue streams (Isa, Chin, \& Mohammad, 2018). It is evident that Muslim tourists participating in halal tourism represent one of the biggest global tourism niche markets that can provide many opportunities for Muslim and non-Muslim countries (Bogan \& Sarusik, 2019).

Mastercard and Crescent rating's (2016, 2018) asserted that, the rising Muslim population and its growing middle class with higher disposable income levels, coupled with increasing access to travel information and the ready availability of Muslim-friendly travel services and facilities, travelling during the Ramadhan fasting period and travelling for business are key drivers of Muslim travel market growth. 
Moreover, it was reported by the Pew Research Centre (2011) that, the world's Muslim population is projected to reach 2.2 billion in 2030 and Muslims will account for $26.4 \%$ of the world's total projected population of 8.3 billion in 2030 .

In 2017, it was determined that 131 million Muslim tourists took part in tourism activities globally. It has been forecasted that these numbers will reach 156 million visitors by 2020 and will represent $10 \%$ of the global travel segment (Mastercard \& Crescent Rating, 2018).

In Africa (Nigeria inclusive), it was reported by Statista (2021) that, tourism sector recorded 1.2 million visitors in December, 2020. This is contrary to over 6.3 million tourists who arrived in the continent as of December 2019. The negative disparity may be connected with the COVID-19 pandemic that affected the global economy. However, the Nigerian tourism industry has experienced significant growth over the last decade, and the country as a travel destination is becoming an increasingly popular choice for many both domestically, regionally and internationally.

A recent report by the National Bureau of Statistics (NBS, 2017) revealed that, tourism accounted for $34 \%$ of the country's gross domestic product (GDP) and about $20 \%$ of the nation's employment creation. But the novel corona virus pandemic had hugely affected both travel and tourism in the country. According to Oyedero (2020) economy report reveals that, travel into Nigeria reduced by 3.5 million which resulted in a revenue loss of US\$0.7 billion with 91,380 jobs lost.

This is as a result of increase in cancellations of hotel reservations by both local and international tourists resulting in a negative impact on revenue generation due to lockdown during the COVID-19 pandemic. World Bank (2021) reported that, Nigerian tourism sector recorded US\$1.47billion US dollars in 2019, down from US\$1.97billion previous year, this is a change of $25.59 \%$.

Also, travel and tourism contributed 5.1\% of GDP in 2019. There are however, several challenges which affect the ability of the sector service providers in the industry to meet customer expectations. This paper aims to discuss the influencing factors of the 7Ps on the consumer's intent to partake in halal tourism in Kano Nigeria. This is to add value to the existing literature in the halal industry that can inevitably assist marketing practitioners to move forward in applying good marketing strategy towards their target customers.

\section{METHODOLOGY}

The paper employs the Desk study approach as its methodology which was carried out by browsing information sourced from print and electronic media and tourism literature about the development of regular tourism and halal tourism all over the world and from Nigeria in particular. Data was collected from government policies on tourism in Nigeria and from the Nigeria Information Culture and Tourism Ministry. The study also considered the Holy Qur'an and Hadith as source of information on the principles of shariah- compliant tourism.

\section{FINDINGS}

The paper observes that Nigeria as a country has the potential to make tourism a main source of income seeing as it has a diverse range of tourist attractions, a large domestic tourism market and a unique cultural heritage capable of enticing foreign tourists. 


\section{CONCLUSION}

This study discusses a conceptual framework on factors that influence the 7Ps of a consumer's intent to partake of halal tourism in Kano-Nigeria.

Halal tourism is a sub-category of religious tourism geared towards Muslim families who abide by Islamic principles. Islamic teaching affects the behaviour of these Muslim tourists. Therefore, halal tourism providers are required to plan their management and organisations to ensure that their products, prices, promotions, places, processes, people and physical evidence are in line with Islamic principles.

It is important for tourist facilities to operate in accordance with Islamic principles to ensure tourist satisfaction. In conclusion, developing tourism products according to Islam, requires consideration of some intangibles and tangible elements, availability halal food, clothing, places of worship, religion and gender of hotel facilities, the provision of entertainment centers and public spaces.

\section{CONTRIBUTION/RECOMMENDATIONS}

The study recommends that, the Nigerian government should establish an agency that would be saddled with responsibility in marketing and regulating halal tourism activity in the country.

There is need by government sat all levels to shift in the education dynamics to be a strong working tie between the academia (primary custodian of knowledge) and the industry (primary users of knowledge) in the halal industry. Also, governments at all levels need to make investors protection shift from institutional uncertainty to established order not just in policy statements but in the actions of its employees in the halal industry because emerging market investors are mostly concerned with level of protection that the operating environment offers such as clarity of economic policies, application and institutional enforcement of rules etc.

The Government should increase its spending to support local halal industry in the area of grant, conferences and workshops that will enlighten halal industry players on how to go with halal investment in Nigeria. It is generally recommended that Nigerian government should encourage the establishment of halal tourism organizations by marketing practitioners (both within and at international level) to consider Nigeria as a potential market hub for the halal tourism business.

The current study was design on conceptual framework using the 7 Ps marketing mix variables and limited to Kano state only. Future empirical research should be conducted to identify more variables that may influence consumers intent to partake in or make use of halal tourism in Nigeria. This will offer more insight on other related independent variables that affects purchase intention in the halal industry.

\section{ACKNOWLEDGEMENTS}

The Nigeria Police Academy supports this work through the Tertiary Education Trust Fund (TETFund. 2019/2020 sponsorship)

\section{REFERENCES}

Bogan, E., \& Sarusik, M. (2019). Halal tourism: Conceptual and practical challenges. Journal of Islamic Marketing, 10(1), 87-96. https://doi.org/10.1108/JIMA-06-2017- 0066

Isa, S. M., Chin, P. N., \& Mohammad, N. U. (2018). Muslim tourist perceived value: A study on Malaysia Halal tourism. Journal of Islamic Marketing. 
Mastercard and CrescentRating. (2016). "Global Muslim travel index 2016". www. crescentrating.com/ halal-muslim-travel-market-reports.html (accessed 18 April2018).

Mastercard and CrescentRating. (2018). "Global Muslim travel index 2018". www. crescentrating.com/ halal-muslim-travel-market-reports.html (accessed 18 April2018).

Oyedero, O. (2020). Tourism in Nigeria: Post COVID 19 era.

Pew Research Center. (2011). "The future of the global Muslim population: Projections for 2010-2030". available at: World Bank. (2017). World development report 2017: Governance and the law. The World Bank.

www.pewforum.org/2011/01/27/the-future-of-the-global-muslim-population/ (accessed 18April2018).

www.stattsta.com 